\title{
Genotoxicity on Tradescantia pallida var. purpurea plants exposed to urban and rural environments in the metropolitan area of Porto Alegre, southern Brazil
}

\author{
Costa, GM. and Droste, A.* \\ Programa de Pós-graduação em Qualidade Ambiental, Universidade Feevale, \\ Rod. RS-239 2755, CEP 93352-000, Novo Hamburgo, RS, Brazil \\ *e-mail: annette@feevale.br
}

Received July 19, 2011- Accepted February 29, 2012 - Distributed November 30, 2012

(With 1 figure)

\begin{abstract}
The Trad-MCN bioassay was used to investigate the genotoxicity on Tradescantia pallida var. purpurea plants exposed to variations in the environmental conditions in urban and rural sites in the metropolitan area of Porto Alegre, southern Brazil, over a one-year period. In spring 2009 and in summer, autumn and winter 2010, potted plants of T. pallida var. purpurea were exposed at two sites with different characteristics: the urban area of the municipality of Estância Velha, with leather and footwear industrial activity, and a Site of Special Environmental Interest in the rural area of the municipality of Novo Hamburgo. Other plants comprised the control group and were kept indoors. Frequencies of micronuclei (MCN) were determined in early tetrads of pollen mother cells and expressed as MCN/100 tetrads. Climate data were also registered during the experiment. MCN frequencies in the urban area were significantly higher (up to 8.13) than those found in the rural area (up to 1.26) and in the control group (up to 1.10), which did not differ statistically from each other over the year. The higher MCN frequencies observed in the urban site can be attributed to air pollution, but also may have been influenced by microclimatic and daily thermal variation differences between sites. Higher temperatures recorded in spring and summer may have influenced MCN frequencies observed in the urban site. No clear relation was observed between rainfall and MCN frequencies. Similar and high relative humidity percentages were registered over the period of the study. Considering that the bioindicator plant presents an integrated response to abiotic factors such as pollutants and weather conditions, it can be used as an additional tool that can point to synergistic effects of environmental variables on organisms.
\end{abstract}

Keywords: air pollution, biomonitoring, genotoxic risk, micronucleus, weather factors.

\section{Genotoxicidade em plantas de Tradescantia pallida var. purpurea expostas a ambientes urbano e rural na área metropolitana de Porto Alegre, Região Sul do Brasil}

\begin{abstract}
Resumo
O bioensaio Trad-MCN foi utilizado para investigar a genotoxicidade em plantas de Tradescantia pallida var. purpurea expostas a variações nas condições ambientais, em uma área urbana e uma área rural, na região metropolitana de Porto Alegre, Região Sul do Brasil, durante o período de um ano. Na primavera de 2009 e no verão, no outono e no inverno de 2010, plantas de T. pallida var. purpurea em vasos foram expostas em dois pontos amostrais, com diferentes características: a área urbana do município de Estância Velha, com atividade industrial do setor coureiro calçadista, e uma Área de Especial Interesse Ambiental (AEIA), na zona rural do município de Novo Hamburgo. Outras plantas compuseram o grupo controle e foram mantidas em ambiente interno. Frequências de micronúcleos (MCN) foram determinadas em tétrades jovens de células-mãe de grãos de pólen e expressas como MCN/100 tétrades. Dados climáticos também foram registrados durante o experimento. As frequências de MCN na área urbana foram significantemente superiores (até 8,13 ) àquelas encontradas na área rural (até 1,26 ) e no grupo controle (até 1,10 ), as quais não diferiram estatisticamente entre si ao longo do ano. As maiores frequências de $\mathrm{MCN}$ observadas na área urbana podem ser atribuídas à poluição atmosférica, mas também podem ter sido influenciadas por diferenças microclimáticas e de variação térmica diária entre áreas. Temperaturas mais altas registradas na primavera e no verão podem ter influenciado as frequências de MCN observadas na área urbana. Não foi observada uma clara relação entre a pluviosidade e as frequências de MCN. Similares e altas porcentagens de umidade relativa foram registradas ao longo do período de estudo. Considerando-se que a planta bioindicadora apresenta uma resposta integrada a fatores abióticos, tais como poluentes e condições climáticas, esta pode vir a ser utilizada como uma ferramenta adicional, que pode apontar para efeitos sinérgicos de variáveis ambientais sobre os organismos.
\end{abstract}

Palavras-chave: poluição do ar, biomonitoramento, risco genotóxico, micronúcleo, fatores climáticos. 


\section{Introduction}

The process of urbanization and industrialization significantly increases atmospheric contamination by complex mixtures of air pollutants, such as particulate material, nitrogen oxides and carbon, from mobile and stationary sources. Air quality is commonly determined and monitored by physicochemical methods for qualitative and quantitative detection of air pollutants. Based on these assessments, government agencies can establish an upper limit for the concentration of pollutants in the air. However, the impact on biological systems of both combined and synergistic effects of chemicals within complex mixtures remains poorly understood (Isidori et al., 2003; Carreras et al., 2009). Certain species of plants used as bioindicators show long-term response and high sensitivity to air contaminants and can therefore be used for qualitative and quantitative assessment of air pollution, indicating the risks of organisms exposure (Meireles et al., 2009).

Tradescantia $\mathrm{L}$. has been used in the Tradescantiamicronucleus (Trad-MCN) bioassay to assess the mutagenic potential of air pollutants (for review, see Rodrigues et al., 1997; Misík et al., 2011). This assay is based on counting micronuclei $(\mathrm{MCN})$ in early tetrads of pollen mother cells undergoing meiotic division (Ma, 1981). The first bioassays assessing mutagenesis with Tradescantia plants used clone 4430, a hybrid between Tradescantia hirsutiflora Bush and Tradescantia subacaulis Bush (Ma et al., 1978). However, this clone is not well adapted to tropical weather, presenting reduced growth and flowering. In addition, the plants are highly susceptible to parasites and insects when kept outdoors and therefore of limited use in field studies aiming to monitor air pollution (Suyama et al., 2002). Conversely, the wild species Tradescantia pallida var. purpurea can easily adapt to tropical weather and has been used as a bioindicator for the presence of mutagens in certain environmental conditions (Guimarães et al., 2000; Suyama et al., 2002; Mielli et al., 2009).

The importance of biomonitoring is well recognised mainly in studies on the quality of urban environments. However, because of the establishment of mosaics of urban and rural areas, air pollution from sources located in urban cores can reach rural areas, affecting ecosystems and modifying the functioning and behaviour of living organisms (Kopciuch, 2004). The Sinos River Basin, located in Brazil's southernmost state, Rio Grande do Sul, has a complex array of human-altered landscapes, showing massively altered urban areas interspersed with patches of native forest found mainly in rural areas (Figueiredo et al., 2010). The lower section of this basin is part of the metropolitan area of Porto Alegre, with large concentrations of population and industry, which are responsible for several biotic and abiotic changes, such as air pollution (COMITESINOS, 2011). However, there are no programmes involving the use of bioindicators for monitoring air pollution in this region.

This study aimed to investigate the genotoxicity, by means of the Trad-MCN bioassay, on Tradescantia pallida var. purpurea plants exposed to variations in the environmental conditions in urban and rural sites in the metropolitan area of Porto Alegre, southern Brazil and to provide a critical analysis of the possible causes of the genotoxic effects in the plants exposed in the urban environment, thus helping to improve the protocol of this bioassay using T. pallida.

\section{Material and Methods}

\subsection{Study area}

The study was carried out in the lower section of the Sinos River Basin that is part of the metropolitan area of Porto Alegre (capital city of the state of Rio Grande do Sul, Brazil). According to the Koeppen classification, the climate of the region corresponds to the Cfa type, with the warmest month's mean temperature above $22^{\circ} \mathrm{C}$ and rainfall regularly distributed throughout the year (Moreno, 1961).

Plants of Tradescantia pallida var. purpurea were exposed in two sampling sites (Figure 1). Site 1 was located in a core urban area of Estância Velha (29 39' 05.1' S and $51^{\circ} 10^{\prime} 23.9^{\prime \prime} \mathrm{W}$ ), at $40 \mathrm{~m}$ of altitude, accounting for $98 \%$ of the total area of the municipality $\left(21.6 \mathrm{~km}^{2}\right)$. This city has about 42,000 inhabitants, and the main economic activities in the region are leather processing and footwear industry. The vehicle fleet consists of 10,861 cars, 659 trucks, and 122 buses (IBGE, 2011). Site 2 was located in Taimbé, a rural area within the district of Lomba Grande $\left(29^{\circ} 46^{\prime} 51.4^{\prime \prime} \mathrm{S}\right.$ and $\left.50^{\circ} 58^{\prime} 31.6^{\prime \prime} \mathrm{W}\right)$, in the municipality of Novo Hamburgo, at $55 \mathrm{~m}$ of altitude. Lomba Grande has an urban area of $3.5 \mathrm{~km}^{2}$ and a rural area of $148.3 \mathrm{~km}^{2}$, and Taimbé is regarded as a Site of Special Environmental Interest (SSEI) within this region. The activities in the region are geared towards leisure and tourism, family agriculture and farming (Schütz, 2001). Due to their characteristics, both sites have to be considered priority areas in environmental quality studies conducted in the basin, as suggested by Spilki and Tundisi (2010).

Data on rainfall, relative humidity and temperature of the study area were supplied by the weather station no. 83961 , located in the municipality of Campo Bom $\left(29^{\circ}\right.$ $41^{\prime} \mathrm{S}$ and $51^{\circ} 03$ ' $\mathrm{W}$ ) at $25.8 \mathrm{~m}$ of altitude, close to both sampling sites (Figure 1). Both urban and rural sites and the local in which the weather station is located are under similar weather conditions (Buriol et al., 2007).

\subsection{Biomonitoring experiments}

Samples of Tradescantia pallida var. purpurea were grown in pots $(37 \mathrm{~cm} \times 20 \mathrm{~cm} \times 20 \mathrm{~cm})$ containing $4 \mathrm{~kg}$ of commercial soil from the same batch, maintained in open air without shade, at the campus of the university. Plants were watered three times a week. Once a week, $100 \mathrm{~mL}$ of 1/3-strength Hoagland solution was applied to each pot; $100 \mathrm{~mL}$ of an N-P-K fertilizer solution (10-10-10) was applied once a month.

Plants were exposed under full sunlight at the two sampling sites in spring 2009 and in summer, autumn and winter 2010 for a 24-hour period, starting at 9:00 am. A total of 15 pots containing one plant each were exposed 


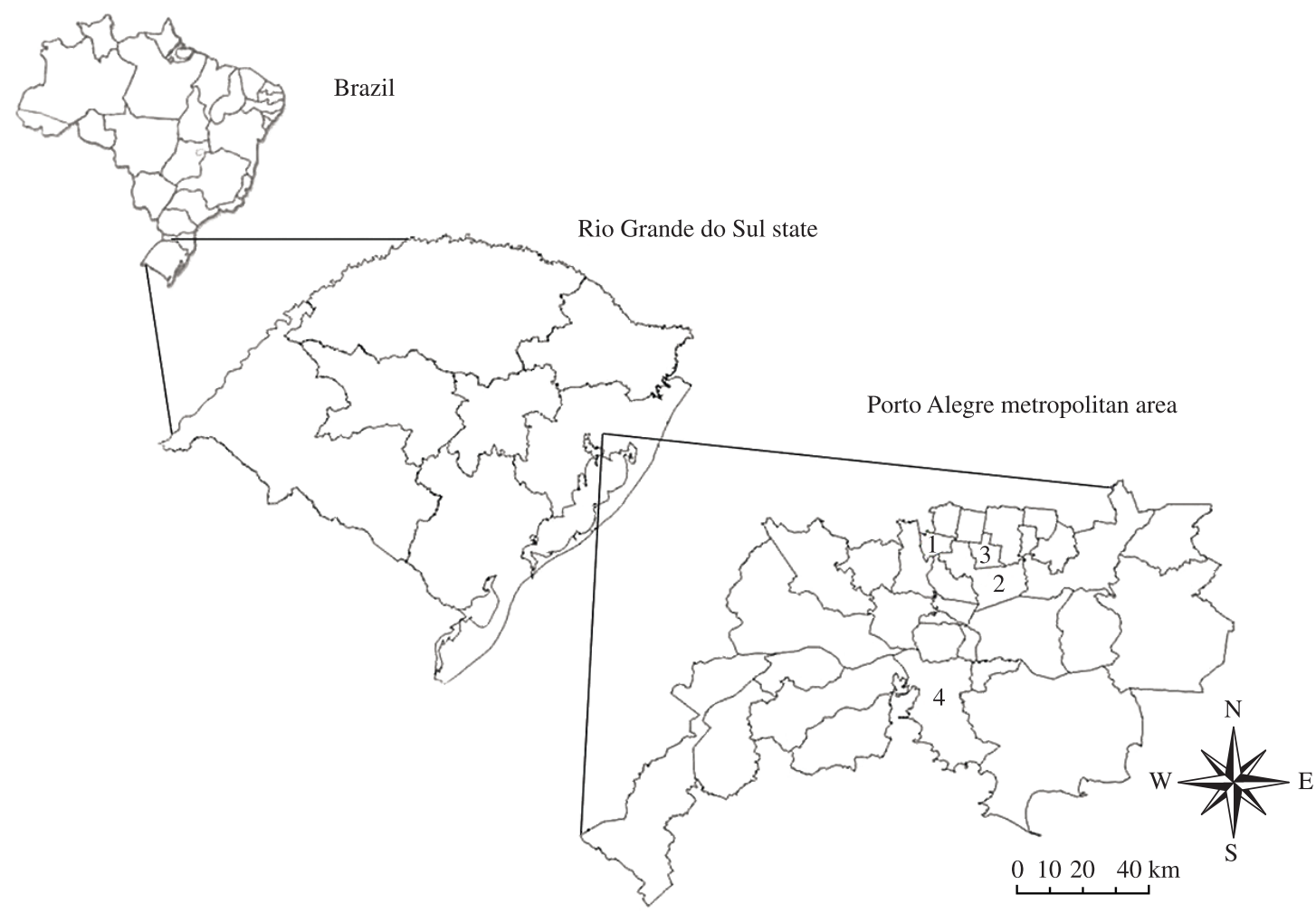

Figure 1. Location of the Tradescantia pallida var. purpurea exposure sites (1 - Estância Velha, 2 - Taimbé) and of the weather station (3) in the metropolitan area of Porto Alegre (4), Rio Grande do Sul state, Brazil.

at each sampling site at the same day. In order to check the frequency of spontaneous micronuclei formed, potted plants were exposed for 24 hours to ambient air in the laboratory acclimation room under constant temperature $\left(26 \pm 1{ }^{\circ} \mathrm{C}\right)$ and natural light (indoor control).

After the 24-hour exposure period, one young inflorescence was collected from each plant. Inflorescences were fixed in ethanol-acetic acid (3:1) solution for 24 hours and stored in $70 \%$ ethanol at $4{ }^{\circ} \mathrm{C}$. The Trad-MCN bioassay was performed as described by Ma (1982). Each bud was dissected and the anthers were squashed in $1 \%$ acetocarmine stain on a slide. Only preparations with early tetrads were considered. Ten slides were prepared for each sample. Slides were coded and the number of $\mathrm{MCN}$ in a random set of 300 tetrads per slide was scored under magnification of 400× (Olympus CX4 microscope). Micronuclei frequencies were calculated by dividing the total number of MCN by the total number of tetrads scored and expressed as MCN/100 tetrads.

\subsection{Statistical analysis}

Data analysis was carried out using the Statistical Package for the Social Sciences version 17.0 (SPSS, Chicago, IL, USA). Data were expressed as mean \pm standard deviation (SD). The normal distribution of variables was verified by the Shapiro-Wilk test. Statistical differences in MCN frequencies were analyzed using the nonparametric KruskalWallis test, followed by Dunn's test, at 5\% probability.

\section{Results}

MCN frequencies observed in the urban area of Estância Velha (site 1) showed significant differences over the seasons of the year: data obtained in spring and summer were similar, but higher than those observed in autumn and winter. Conversely, in the rural area of Taimbé (site 2), no significant differences were observed in MCN frequencies over the four seasons of the year. However, significant differences were observed when data from both sampling sites and the indoor control group were compared by season. Over the four seasons of the year, $\mathrm{MCN}$ frequencies in the urban area were higher than those found in the rural area and in the control, which were statistically not different from each other (Table 1).

Typical climate conditions for the metropolitan region of Porto Alegre were observed during the exposure of Tradescantia pallida var. purpurea plants (Table 2). The hottest days of exposure occurred in spring and summer and the coldest day was registered in winter. The relative humidity at the first hour of exposure varied from $79 \%$ in spring to $97 \%$ in autumn. No rainfall was observed during the exposures, but a high volume was registered in the two days before the exposure in summer. 
Table 1. Frequency of micronuclei (MCN) in Tradescantia pallida var. purpurea exposed at two sampling sites in the metropolitan area of Porto Alegre, Rio Grande do Sul state, Brazil.

\begin{tabular}{|c|c|c|c|c|c|c|}
\hline \multirow{2}{*}{ Sampling site } & Spring & Summer & Autumn & Winter & \multirow{2}{*}{$\mathbf{H}$} & \multirow{2}{*}{$\mathbf{P}$} \\
\hline & \multicolumn{4}{|c|}{ MCN frequency $($ mean \pm SD) } & & \\
\hline $\begin{array}{l}\text { Estância Velha } \\
\text { (urban area) }\end{array}$ & $8.13 \pm 1.78^{\mathrm{bB}}$ & $7.60 \pm 1.55^{\mathrm{bB}}$ & $3.26 \pm 0.70^{\mathrm{aB}}$ & $4.13 \pm 0.93^{\mathrm{aB}}$ & 29.962 & $<0.001$ \\
\hline Taimbé (rural area) & $1.26 \pm 0.73^{\mathrm{aA}}$ & $1.13 \pm 0.32^{\mathrm{aA}}$ & $1.03 \pm 0.48^{\mathrm{aA}}$ & $1.03 \pm 0.46^{\mathrm{aA}}$ & 0.966 & 0.809 \\
\hline Indoor control & $1.03 \pm 0.68^{\mathrm{aA}}$ & $1.10 \pm 0.94^{\mathrm{aA}}$ & $1.13 \pm 0.57^{\mathrm{aA}}$ & $0.96 \pm 0.63^{\mathrm{aA}}$ & 0.472 & 0.925 \\
\hline $\mathrm{H}$ & 19.577 & 19.861 & 19.669 & 19.224 & & \\
\hline $\mathrm{P}$ & $<0.001$ & $<0.001$ & $<0.001$ & $<0.001$ & & \\
\hline
\end{tabular}

$\mathrm{H}=$ Kruskal-Wallis test; $\mathrm{P}=$ probability; $\mathrm{SD}=$ standard deviation. Means with different upper case letters in the same column and means with different lower case letters in the same line are significantly different by Dunn's test.

Table 2. Temperature, relative humidity and rainfall in the study area during the exposure of Tradescantia pallida var. purpurea plants.

\begin{tabular}{|c|c|c|c|c|c|c|c|c|}
\hline \multirow{3}{*}{ Season } & \multirow{2}{*}{\multicolumn{3}{|c|}{$\begin{array}{c}\text { Temperature }\left({ }^{\circ} \mathbf{C}\right) \\
\text { Day of exposure }\end{array}$}} & \multirow{2}{*}{\multicolumn{3}{|c|}{$\begin{array}{c}\text { Relative humidity }(\%) \\
\text { Day of exposure }\end{array}$}} & \multicolumn{2}{|c|}{ Rainfall (mm) } \\
\hline & & & & & & & \multirow{2}{*}{ Day of exposure } & \multirow{2}{*}{ Two days before } \\
\hline & 9 hours & 15 hours & 21 hours & 9 hours & 15 hours & 21 hours & & \\
\hline Spring & 25.8 & 27.8 & 23.3 & 79 & 75 & 88 & 0.0 & 0.0 \\
\hline Summer & 22.4 & 26.0 & 21.4 & 96 & 73 & 78 & 0.0 & 82.1 \\
\hline Autumn & 13.3 & 26.8 & 16.6 & 97 & 61 & 95 & 0.0 & 0.2 \\
\hline Winter & 6.5 & 25.0 & 15.0 & 96 & 56 & 89 & 0.0 & 0.3 \\
\hline
\end{tabular}

\section{Discussion}

Genotoxicity observed in the urban site was significantly higher than in both rural site and indoor control. Considering the chemical data of air quality obtained for three years (2006-2008) by the monitoring station of a state foundation for environmental protection (Fundação Estadual de Proteção Ambiental Henrique Luiz Roessler, FEPAM), the urban site possibly presents a higher level of atmospheric contamination, with wide variations of sulfur dioxide and particulate material concentrations. Low MCN frequencies observed in the four seasons of the year in the rural area under study may be an indicative of no potential genotoxic risks to living organisms. Despite being close to polluted urban cores, this site may be referred to as a white spot.

Genotoxic effects on Tradescantia in environments with traffic and industrial emissions and comparatively lower MCN frequencies in apparently not polluted areas were also registered in studies with the clone 4430 in several European cities (Klumpp et al., 2006) and with Tradescantia pallida var. purpurea in Varanasi, India (Prajapati and Tripathi, 2008), Córdoba, Argentina (Carreras et al., 2009), and in the Brazilian cities of São Paulo (Guimarães et al., 2000), Feira de Santana (Meireles et al., 2009) and Santo André (Savóia et al., 2009). These studies indicate that environmental conditions present at urban sites were stressing enough to increase chromosomal breakage in the pollen mother cells (Savóia et al., 2009).
In the present study, a pilot test revealed that MCN frequencies of plants exposed during 6 hours to the urban site with recovery time of 24 hours were lower than those observed in samples exposed during 24 hours without recovery time (unpublished data). The duration of plant exposure can vary according with the level of the pollutants (Ma, 1981). An exposure period of 24 hours has been used for air monitoring using cuttings of the clone 4430 (Isidori et al., 2003; Villarini et al., 2009). However, longer exposure times at low to moderate pollution levels exposes the plants to unfavorable weather conditions that can interfere with the performance of the test (Klumpp et al., 2004). Lima et al. (2009) observed maximal genotoxic responses to ozone from 72 hours after exposure on. The authors emphasize that the significant increase in the $\mathrm{MCN}$ rates verified in inflorescences from the control after 72-120 hours of recovery indicates that the procedures of the bioassay per se were stressful.

The short-term exposure without adaptation and recovery times may have contributed to a possible nonspecific response of the plants in the urban area, since the genotoxic effect can have occurred in response to environmental conditions present in the first hours of each exposure. Most studies do not mention the environmental conditions in which the bioassays are performed. However, some works pointed to the influence of climatic factors, especially rainfall, relative humidity and temperature, on the formation of micronuclei 
using clone 4430 (Isidori et al., 2003; Klumpp et al., 2004, 2006) and Tradescantia pallida var. purpurea (Meireles et al., 2009; Lima et al., 2009; Savóia et al., 2009). Although lower MCN frequencies have been related to higher rain volumes, probably due to the dispersion of pollutants in the atmosphere (Ferreira et al., 2003), no clear relation could be observed in the present study. In summer, when high MCN frequencies were observed in the urban site, rainfall two days before sampling was of $82 \mathrm{~mm}$. On the other hand, no rainfall occurred in a one week period prior to sampling in the spring, although the MCN frequencies were also high. Concerning relative humidity, similar and high percentages were registered over the period of the study, corroborating the typical climatic conditions that characterize the state of Rio Grande do Sul, without an absolute distinction of humidity percentages among seasons. Therefore, stomata should have been open during the exposures, not hindering the uptake of gaseous substances.

Higher MCN frequencies observed in the urban area in spring and summer may have been influenced by higher temperatures recorded in these seasons, especially at the first hour of exposure. Furthermore, microclimatic differences between the study areas may have occurred, since urban areas are generally warmer than rural areas. Daily thermal variation can also influence the frequency of MCN (Isidori et al., 2003; Klumpp et al., 2004; Lima et al., 2009). However, in the present study, the highest daily thermal amplitudes were registered in autumn and winter, seasons in which the MCN frequencies were lower.

Considering that the bioindicator plant presents an integrated response to abiotic factors such as pollutants and weather conditions (Klumpp et al., 2004; Lima et al., 2009; Savóia et al., 2009), bioindication is not able to replace the physicochemical monitoring of air quality, but can be used as an additional tool that can point to synergistic effects of environmental variables on living organisms. To this end, further studies are needed to understand the interaction between Tradescantia pallida var. purpurea and the abiotic variables and to improve the bioassay using this species.

Acknowledgements - The authors thank the Universidade Feevale for the use of laboratories, the Coordenação de Aperfeiçoamento de Pessoal de Nível Superior (CAPES) for the scholarship granted to the first author, D. Endres Júnior and M. H. Sasamori for editing the figure.

\section{References}

BURIOL, GA., ESTEFANEL, V., CHAGAS, AC. and EBERHARDT, D., 2007. Clima e vegetação natural do Rio Grande do Sul segundo o diagrama climático de Walter e Lieth. Ciência Florestal, vol. 17, p. 91-100.

CARRERAS, HA., RODRIGUEZ, JH., GONZALEZ, CM., WANNAZ, ED., FERREYRA, FG., PEREZ, CA. and PIGNATA, ML., 2009. Assessment of the relationship between total suspended particles and the response of two biological indicators transplanted to an urban area in central Argentina. Atmospheric Environment, vol. 43, p. 2944-2949. http://dx.doi.org/10.1016/j.atmosenv.2009.02.060
Comitê de Gerenciamento da Bacia Hidrográfica do Rio dos Sinos - COMITESINOS. Available from: http://www.comitesinos. com.br. Access in: 25 jun. 2011.

FERREIRA, MI., RODRIGUES, GS., DOMINGOS, M. and SALDIVA, PHN., 2003. In situ monitoring of mutagenicity of air pollutants in São Paulo city using Tradescantia-SHM bioassay. Brazilian Archives of Biology and Technology, vol. 46, no. 2, p. 253-258. http://dx.doi.org/10.1590/S1516-89132003000200017

FIGUEIREDO, JAS., DRUMM, E., RODRIGUES, MAS. and SPILKI, FR., 2010. The Rio dos Sinos watershed: an economic and social space and its interface with environmental status. Brazilian Journal of Biology, vol. 70, no. 4 Suppl., p.1131-1136. PMid:21225153.

GUIMARÃES, ET., DOMINGOS, M., ALVES, ES., CALDINI, JRN., LOBO, DJA., LICHTENFELS, AJFC. and SALDIVA, PHN., 2000. Detection of the genotoxicity of air pollutants in and around the city of São Paulo (Brazil) with the Tradescantiamicronucleus (Trad-MCN) assay. Environmental and Experimental Botany, vol. 44, no. 1, p.1-8. PMid:10927123.

Instituto Brasileiro de Geografia e Estatística - IBGE. Available from: http://www.ibge.gov.br/cidadesat/link.php?uf=rs. Access in: 25 jun. 2011.

ISIDORI, M., FERRARA, M., LAVORGNA, M., NARDELLI, A. and PARRELA, A., 2003. In situ monitoring of urban air in Southern Italy with the Tradescantia micronucleus bioassays and semipermeable membrane devices (SPMDs). Chemosphere, no. 52, p. 121-126. http://dx.doi.org/10.1016/S0045-6535(03)00183-8

KLUMPP, A., ANSEL, W., FOMIN, A., SCHNIRRING, S. and PICKL, C., 2004. Influence of climatic conditions on the mutations in pollen mother cells of Tradescantia clone 4430 and implications for the Trad-MCN bioassay protocol. Hereditas, vol. 141, p. 142-148. PMid:15660975. http://dx.doi.org/10.1111/j.16015223.2004.01806.X

KLUMPP, A., ANSEL, W., KLUMPP, G., CALATAYUD, V., GARREC, JP., HE, S., PENUELAS, J., RIBAS, A., ROPOULSEN, H., RASMUSSEN, S., SANZ, MJ. and VERGNE, P., 2006. Tradescantia micronucleus test indicates genotoxic potential of traffic emissions in European cities. Environmental Pollution, vol. 139, p. 515-522. PMid:16098647. http://dx.doi. org/10.1016/j.envpol.2005.05.021

KOPCIUCH, RG., 2004. Some considerations about bioindicators in environmental monitoring. Polish Journal of Environmental Studies, vol. 13, no. 5, p.453-462.

LIMA, ES., SOUZA, SR. and DOMINGOS, M., 2009. Sensitivity of Tradescantia pallida (Rose) Hunt. 'Purpurea' Boom to genotoxicity induced by ozone. Mutation Research, vol. 675, p. 41-45. PMid:19386246. http://dx.doi.org/10.1016/j.mrgentox.2009.02.007

MA, TH., 1981. Tradescantia micronucleus bioassay and pollen tube chromatic aberration test for in situ monitoring and mutagens screening. Environmental Health Perspectives, vol. 37, p. 85-90. PMid:7460887 PMCid:1568629.

MA, TH., 1982. Tradescantia cytogenetic tests (root-tip mitosis, pollen mitosis, pollen mother-cell meiosis). A report of the U.S. Environmental Protection Agency Gene-Tox Program. Mutation Research, vol. 99, p. 293-302. PMid:7177155.

MA, TH., SPARROW, AH., SCHAIRER, LA. and NAUMAN, AF., 1978. Effect of 1,2dibromoethane (DBE) on meiotic chromosomes of Tradescantia. Mutation Research, vol. 58, p. 251-258. http://dx.doi.org/10.1016/0165-1218(78)90016-2 
MEIRELES, J., ROCHA, R., COSTA NETO, A. and CERQUEIRA, E., 2009. Genotoxic effects of vehicle traffic pollution as evaluated by micronuclei test in Tradescantia (Trad-MCN). Mutation Research, vol. 675, p. 46-50. PMid:19386247. http://dx.doi. org/10.1016/j.mrgentox.2009.02.005

MIELLI, AC., MATTA, MEM., NERSESYAN, A., SALDIVA, PHN. and UMBUZEIRO, GA., 2009. Evaluation of the genotoxicity of treated urban sludge in the Tradescantia micronucleus assay. Mutation Research, vol. 672, p. 51-54. PMid:18940264. http:// dx.doi.org/10.1016/j.mrgentox.2008.09.007

MISÍK, M., MA, TH., NERSESYAN, A., MONARCA, S., KIM, JK. and KNASMUELLER, S., 2011. Micronucleus assays with Tradescantia pollen tetrads: an update. Mutagenesis, vol. 26, no. 1, p. 215-221. PMid:21164205. http://dx.doi.org/10.1093/ mutage/geq080

MORENO, JA., 1961. Clima do Rio Grande do Sul. Porto Alegre: Governo do Estado do Rio Grande do Sul, Secretaria da Agricultura. 41 p.

PRAJAPATI, SK. and TRIPATHI, BD., 2008. Assessing the genotoxicity of urban air pollutants in Varanasi City using Tradescantia micronucleus (Trad-MCN) bioassay. Environment International, vol. 34, p. 1092-1096. PMid:18455797. http:// dx.doi.org/10.1016/j.envint.2008.03.009

RODRIGUES, GS., MA, TH., PIMENTEL, D. and WEISTEIN, LH., 1997. Tradescantia bioassays as monitoring system for environmental mutagenesis: a critical review. Critical Review in Plant Science, vol. 16, no. 4, p. 335-359.

SAVÓIA, EJ., DOMINGOS, M., GUIMARÃES, ET., BRUMATI, F. and SALDIVA, PH., 2009. Biomonitoring genotoxic risks under the urban weather conditions and polluted atmosphere in Santo André, SP, Brazil, through Trad-MCN bioassay. Ecotoxicology and Environmental Safety, vol. 72, p. 255-260. PMid:18571723. http://dx.doi.org/10.1016/j.ecoenv.2008.03.019

SCHÜTZ, LMM., 2001. Os bairros de Novo Hamburgo. Novo Hamburgo: CIP - Brasil Catalogação na Publicação. 196 p.

SPILKI, F. and TUNDISI, JG., 2010. Priority targets for environmental research in the Sinos River Basin. Brazilian Journal of Biology, vol. 70, no. 4 Suppl., p.1245-1247. http:// dx.doi.org/10.1590/S1519-69842010000600014

SUYAMA, F., GUIMARÃES, ET., LOBO, DJA., RODRIGUES, GS., DOMINGOS, M., ALVES, ES., CARVALHO, HA. and SALDIVA, PHN., 2002. Pollen mother cells of Tradescantia clone 4430 and Tradescantia pallida var. purpurea are equally sensitive to the clastogenic effects of X-rays. Brazilian Journal of Medical and Biological Research, vol. 35, p. 127-129. PMid:11743625. http:// dx.doi.org/10.1590/S0100-879X2002000100018

VILLARINI, M., FATIGONI, C., DOMINICI, L., MAESTRI, S., EDERLI, L., PASQUALINI, S., MONARCA, S. and MORETTI, M., 2009. Assessing the genotoxicity of urban air pollutants using two in situ plant bioassays. Environmental Pollution, vol. 157, p. 3354-3356. PMid:19836119. http://dx.doi.org/10.1016/j. envpol.2009.09.012 